\title{
GAMBARAN HISTOPATOLOGI LAMBUNG TIKUS WISTAR (Rattus norvegicus) YANG DIBERIKAN LENGKUAS (Alpinia galanga Willd) SETELAH DIINDUKSI OLEH ASAM MEFENAMAT
}

\author{
1 Juita Pasaribu \\ ${ }^{2}$ Lily Loho \\ ${ }^{2}$ Poppy Lintong
}

\author{
${ }^{1}$ Kandidat Skripsi Fakultas Kedokteran \\ ${ }^{2}$ Bagian Patologi Anatomi Fakultas Kedokteran Universitas Sam Ratulangi Manado \\ Email: paai_manado@yahoo.com
}

\begin{abstract}
Abstrak: Gastritis akut merupakan proses inflamasi yang bersifat akut dan biasanya terjadi pada bagian permukaan mukosa lambung. Penyakit ini biasanya disebabkan karena banyak faktor salah satunya yaitu penggunaan asam mefenamat dalam dosis yang berlebihan. Pada penelitian yang telah dilakukan sebelumnya didapatkan bahwa lengkuas dapat mengurangi terjadinya radang akut. Tujuan penelitian ini adalah untuk mengetahui gambaran histopatologi lambung tikus wistar yang diberikan lengkuas setelah diinduksi dengan asam mefenamat. Penelitian ini menggunakan metode eksperimental dengan sampel 11 ekor tikus wistar yang dibagi dalam 4 kelompok perlakuan. Kelompok A tidak diberikan perlakuan. Kelompok B diberikan asam mefenamat $10 \mathrm{mg}$ selama 7 hari. Kelompok C diberikan asam mefenamat 10 mg selama 7 hari kemudian diberikan perasan lengkuas selama 7 hari. Kelompok D diberikan asam mefenamat $10 \mathrm{mg}$ kemudian tidak diberikan perlakuan selama 7 hari. Hasil penelitian ini menunjukkan bahwa gambaran mikroskopik lambung tikus wistar pada kelompok $\mathrm{C}$ terdapat sel-sel radang PMN yang lebih sedikit dibandingkan dengan kelompok B dan D. Simpulan: lengkuas dapat mengurangi sel-sel radang PMN pada mukosa lambung yang diberikan dengan asam mefenamat.
\end{abstract}

Kata kunci: Lengkuas, Asam Mefenamat, Gastritis akut.

\begin{abstract}
: acute gastritis is an acute inflammatory process normally occurring in the mucosal lining of the stomach. This disease is caused by a variety of factors, one of which is the use of mefenamat acid in large doses. Previous research has revealed that galangal can be used to reduce acute inflammation. The objective of this research was to reveal the histopathological pictures of stomach of wistar rats that treatment with galangal after induce by mefenamat acid. This study is an experimental, employing 11 wistar rats which were assigned for four treatment groups. Group A was the control group in which the rats received no treatment. Rats in group B were administered mefenamat acid $10 \mathrm{mg}$ for 7 days. In group C, the rats were also administered mefenamat acid $10 \mathrm{mg}$ for 7 days and then received galangal distillation for 7 days. In group D, rats were administered mefenamat acid $10 \mathrm{mg}$ for 7 days and then for 7 days without receiving anymore mefenamat acid or galangal distillation. Results showed that microscopic pictures of stomach of wistar rats in group C were presented with PMN inflammatory cells fewer than rats in group B and D. Conclusion: galangal can reduce PMN inflammatory cells in mucosal lining of the stomach exposed to mefenamat acid.
\end{abstract}

Key words: galangal, mefenamat acid, acute gastritis. 
Lengkuas ( Alpinia galanga Willd) merupakan tumbuhan apotik hidup yang dapat tumbuh di dataran tinggi maupun dataran rendah. Tanaman ini telah dikenal dan digunakan sejak ribuan tahun yang lalu karena manfaatnya dalam pengobatan. Lengkuas memiliki banyak kandungan nutrisi, seperti: 0,5-1,5\% minyak atsiri berwarna kuning kehijauan terutama terdiri dari metal-sinamat 48\%, 1,8 sienol 5,6\%, eugenol dan asetoksikavikol asetat. Tanaman ini memiliki khasiat sebagai anti radang, antimikroba, antioksidan, dan antifungi. ${ }^{1}$

Lambung merupakan bagian dari saluran pencernaan yang banyak mendapatkan paparan dengan bahan-bahan yang merusak mukosanya. Kerusakan mukosa lambung paling banyak disebabkan penggunaan obat anti inflamasi non steroid (NSAID). ${ }^{2,3}$ Obat anti inflamasi yang paling sering digunakan masyarakat adalah asam mefenamat. Obat ini merupakan bahan yang dapat menembus barrier mukosa lambung sehingga sering dilaporkan asam mefenamat memberi efek iritasi terhadap mukosa lambung. Asam mefenamat dapat menyebabkan pengelupasan pada sel epitel permukaan dan mengurangi sekresi mukus yang merupakan barrier protektif terhadap asam. ${ }^{3}$ Asam mefenamat bekerja dengan cara menekan produksi prostaglandin. Efek iritasi pada mukosa lambung ini dapat menyebabkan gastritis akut. ${ }^{4}$ Pada gambaran makroskopik gastritis akut terlihat hiperemia serta edema yang sedang dan kadang-kadang disertai perdarahan. Gambaran mikroskopik tampak edema lamina propria dan sebukan sel netrofil pada permukaan epitel atau dalam mukosa. ${ }^{5,6,7}$

Beberapa penelitian membuktikan bahwa lengkuas (Alpinia galanga Willd) memiliki khasiat terhadap kesehatan pada lambung. Penelitian pada tikus yang diberi ekstrak lengkuas dengan dosis $500 \mathrm{mg} /$ $\mathrm{kgBB} /$ hari setelah diberikan indometasin dosis $30 \mathrm{mg} / \mathrm{kgBB}$ menunjukkan sekresi asam lambung menurun dan berkurangnya sel-sel radang pada lambung setelah pemberian ekstrak lengkuas. ${ }^{8,9}$ Penelitian ini bertujuan untuk melihat bagaimana gambaran histopatologi lambung tikus wistar yang diberikan lengkuas setelah diinduksi asam mefenamat.

\section{METODOLOGI PENELITIAN}

Jenis penelitian yang dilakukan adalah penelitian eksperimental. Penelitian dilakukan di laboratorium Riset Biomedik dan Laboratorium Patologi Anatomi Fakultas Kedokteran Universitas Sam Ratulangi Manado. Alat dan bahan yang digunakan: blender, kain kasa/saringan, NGT pediatric no5, semprit $1 \mathrm{ml}$, object glass, kamera mikroskop digital, rimpang lengkuas segar, pellet AD2, asam mefenamat $500 \mathrm{mg}$.

Subjek penelitian ini adalah 11 ekor tikus wistar dalam keadaan sehat yang terdiri dari: 2 ekor kontrol negatif dan 9 ekor perlakuan yang dibagi dalam 4 kelompok:

a. Kelompok A sebagai kelompok kontrol negatif. Kelompok ini terdiri dari 2 ekor tikus wistar, diberikan makanan berupa pelet tanpa asam mefenamat maupun perasan lengkuas selama 7 hari kemudian diterminasi hari ke 8. Lalu dilakukan pembedahan untuk diperolehnya lambung dan dilakukan pengamatan secara makroskopik dan mikroskopik.

b. Kelompok B sebagai kelompok perlakuan 1. Terdiri dari 3 tikus wistar yang diberikan pelet dan asam mefenamat dengan dosis $10 \mathrm{mg} / \mathrm{hari}$ selama 7 hari kemudian diterminasi hari ke 8. Lalu dilakukan pembedahan untuk diperolehnya lambung dan dilakukan pengamatan secara makroskopik dan mikroskopik.

c. Kelompok C sebagai kelompok perlakuan 2. Terdiri dari 3 tikus wistar yang diberikan asam mefenamat dosis $10 \mathrm{mg}$ per hari selama 7 hari lalu dilanjutkan dengan pemberian perasan lengkuas 16 mg melalui NGT selama 7 hari dan diterminasi hari ke 15. Lalu dilakukan terminasi, dilakukan pengamatan secara makroskopik dan mikroskopik.

d. Kelompok D sebagai kelompok perlakuan 3. Terdiri dari 3 tikus wistar 
yang diberikan asam mefenamat dosis $10 \mathrm{mg}$ per hari selama 7 hari lalu diberikan pelet biasa selama 7 hari kemudian diterminasi hari ke 15. Lalu dilakukan terminasi, dilakukan pengamatan secara makroskopik dan mikroskopik.

\section{HASIL PENELITIAN}

\section{Gambaran makroskopik}

Penilaian secara makroskopik dimulai pada saat otopsi melalui pengamatan war- na, perabaan konsistensi dan permukaan, serta penimbangan berat lambung tikus (Tabel 1). Gambaran makroskopik tikus kontrol dan perlakuan dapat dilihat gambar 1.

\section{Gambaran mikroskopik}

\section{Tikus wistar kontrol negatif}

Pada tikus wistar kelompok kontrol negatif didapatkan gambaran histologi dinding lambung yang normal. Pada sediaan lambung ini, bagian mukosa lambung tidak terdapat sel-sel radang (Gambar 2).

Tabel 1. Warna, konsistensi,permukaan dan berat lambung tikus wistar

\begin{tabular}{|c|c|c|c|c|c|}
\hline Kelompok & Perlakuan & Warna & Konsistensi & Permukaan & $\begin{array}{c}\text { Berat } \\
\text { (gram) }\end{array}$ \\
\hline I A & Kontrol Negatif & Merah muda & Kenyal & Halus & $2,94 \mathrm{gr}$ \\
\hline I B & Kontrol Negatif & Merah muda & Kenyal & Halus & $3,63 \mathrm{gr}$ \\
\hline II A & Asam Mefenamat 10 mg/hari & Merah pucat & Kenyal & Halus & $2,16 \mathrm{gr}$ \\
\hline II B & Asam Mefenamat 10 mg/hari & Merah pucat & Kenyal & Halus & $4,77 \mathrm{gr}$ \\
\hline II C & $\begin{array}{l}\text { Asam Mefenamat } 10 \text { mg/hari } \\
\text { Asam Mefenamat } 10 \text { mg/hari }\end{array}$ & Merah pucat & Kenyal & Halus & $3,61 \mathrm{gr}$ \\
\hline III A & $\begin{array}{l}\text { Dilanjutkan dengan lengkuas } \\
16 \mathrm{mg} / \text { hari }\end{array}$ & Merah pucat & Kenyal & Halus & $4,28 \mathrm{gr}$ \\
\hline III B & $\begin{array}{c}\text { Asam Mefenamat } 10 \mathrm{mg} / \mathrm{hari} \\
\text { Dilanjutkan dengan lengkuas } \\
16 \mathrm{mg} / \mathrm{hari}\end{array}$ & Merah pucat & Kenyal & Halus & $3,43 \mathrm{gr}$ \\
\hline III C & $\begin{array}{c}\text { Asam Mefenamat } 10 \mathrm{mg} / \mathrm{hari} \\
\text { Dilanjutkan dengan lengkuas } \\
16 \mathrm{mg} / \text { hari }\end{array}$ & Merah pucat & Kenyal & Halus & $2,91 \mathrm{gr}$ \\
\hline IV A & $\begin{array}{l}\text { Asam Mefenamat } 10 \mathrm{mg} / \mathrm{hari} \\
\text { Dilanjutkan dengan pelet biasa }\end{array}$ & Merah pucat & Kenyal & Halus & $2,60 \mathrm{gr}$ \\
\hline IV B & $\begin{array}{l}\text { Asam Mefenamat } 10 \mathrm{mg} / \mathrm{hari} \\
\text { Dilanjutkan dengan pelet biasa }\end{array}$ & Merah pucat & Kenyal & Halus & $2,28 \mathrm{gr}$ \\
\hline IV C & $\begin{array}{l}\text { Asam Mefenamat } 10 \mathrm{mg} / \mathrm{hari} \\
\text { Dilanjutkan dengan pelet biasa }\end{array}$ & Merah pucat & Kenyal & Halus & $2,85 \mathrm{gr}$ \\
\hline
\end{tabular}
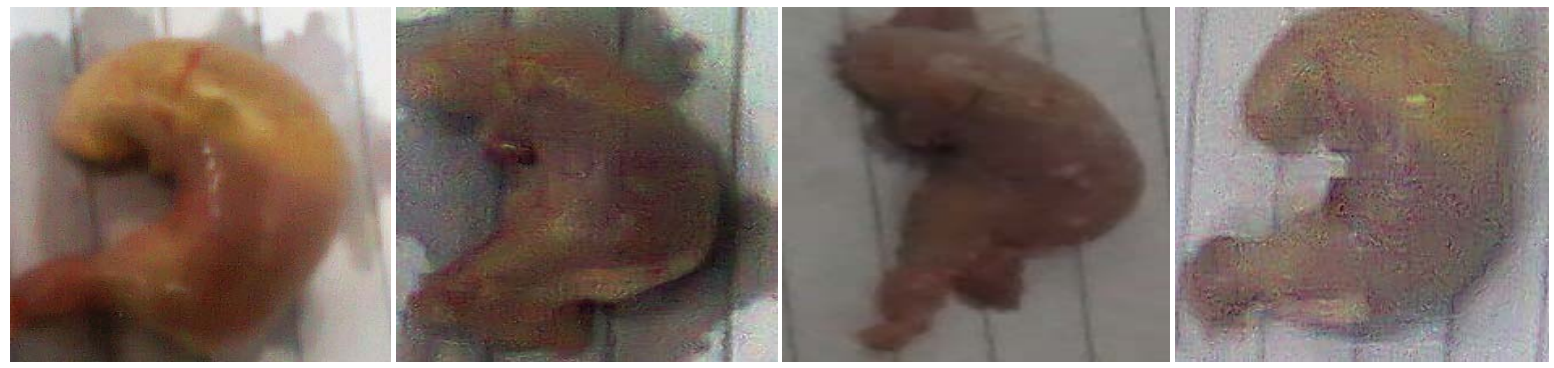

Gambar 1. Gambaran makroskopik lambung tikus wistar kelompok A, B, C, D. 


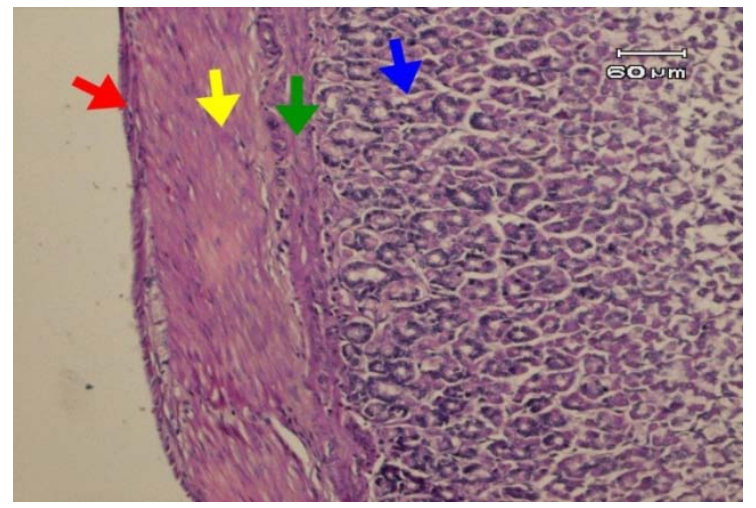

Gambar 2. Gambaran mikroskopik lambung tikus wistar yang hanya diberikan makanan pelet selama 7 hari. Tampak lapisan mukosa (panah biru), submukosa (panah hijau), muskularis eksterna (panah kuning), serosa (panah merah). Tidak terdapat sel-sel radang. Pembesaran 10x10.

\section{Tikus wistar kelompok perlakuan I}

Pada tikus wistar kelompok perlakuan I yang diberi perlakuan asam mefenamat selama 7 hari tampak bagian mukosa lambung masih normal. Pada lapisan bawah mukosa lambung banyak terdapat sel-sel radang limfosit dan PMN. Selain itu, terdapat edema pada lamina propria dan kapiler darah melebar (Gambar 3).

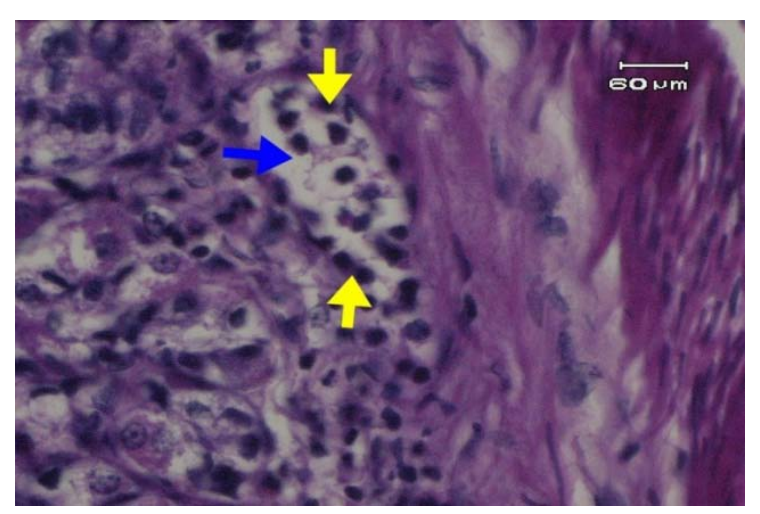

Gambar 3. Gambaran mikroskopik lambung tikus wistar yang diberi asam mefenamat $10 \mathrm{mg}$ selama 7 hari. Tampak infiltrasi sel-sel radang limfosit dan neutrofil daerah bagian bawah mukosa (panah kuning) dan edema lamina propria (panah biru). Pembesaran 10x40.

\section{Tikus wistar kelompok perlakuan II}

Pada tikus wistar kelompok perlakuan
II yang diberi perlakuan asam mefenamat selama 7 hari, kemudian dilanjutkan dengan lengkuas selama 7 hari. Kelompok ini menunjukkan perbaikan struktur lambung, jika dibandingkan dengan kelompok perlakuan satu. Sel-sel radang limfosit dan PMN mulai berkurang dan tidak menyeluruh, edema mulai berkurang (Gambar 4).

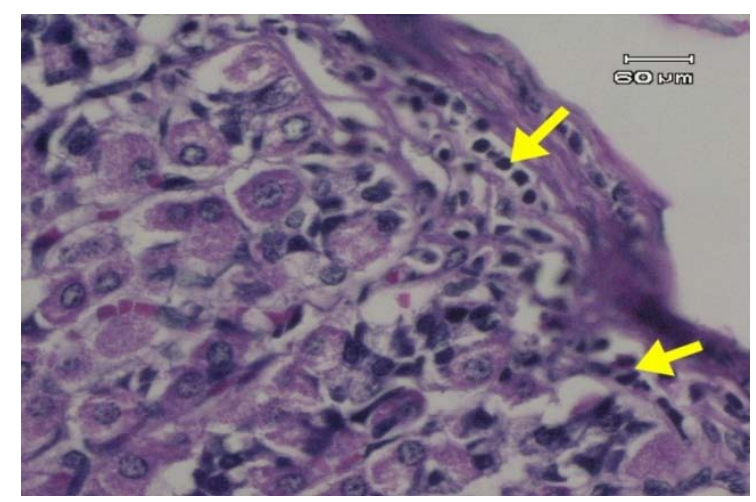

Gambar 4. Gambaran mikroskopik lambung tikus wistar yang diberi asam mefenamat $10 \mathrm{mg}$ selama 7 hari dilanjutkan dengan perasan lengkuas $16 \mathrm{mg}$ selama 7 hari. Tampak sedikit infiltrasi sel-sel radang limfosit dan PMN daerah bagian bawah mukosa (panah kuning). Pembesaran 10x40.

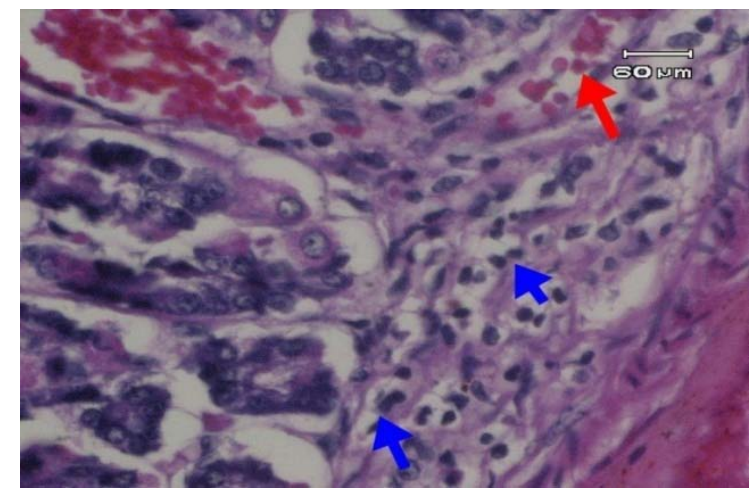

Gambar 5. Gambaran mikroskopik lambung tikus wistar yang diberi asam mefenamat $10 \mathrm{mg}$ selama 7 hari dilanjutkan dengan pelet standar selama 7 hari. Tampak masih banyak infiltrasi sel-sel radang limfosit dan PMN pada daerah bagian bawah mukosa (panah biru), edema mulai berkurang dan kapiler yang berisi eritrosit (panah merah). Pembesaran 10x40.

\section{Tikus wistar kelompok perlakuan III}

Kelompok tikus wistar perlakuan III 
merupakan kelompok tikus yang diberi perlakuan asam mefenamat selama 7 hari, kemudian dilanjutkan pemberikan pelet biasa selama 7 hari. Kelompok ini menunjukkan gambaran mikroskopik yaitu sebagian kecil sel-sel radang pada bagian bawah mukosa lambung berkurang dibandingkan kelompok perlakuan II (Gambar 5).

\section{BAHASAN}

Pada kelompok kontrol negatif menunjukkan gambaran makroskopik lambung yang normal, baik warna, konsistensi, dan permukaan. Begitu juga pada gambaran mikroskopik menunjukkan mukosa, submukosa, muskularis, dan serosa tampak normal dan tidak terdapat sel-sel radang.

Gambaran makroskopik lambung kelompok perlakuan pemberian asam mefenamat $10 \mathrm{mg}$ per hari selama 7 hari tampak agak pucat dan dinding lambung juga tampak lebih menipis dibandingkan dengan kelompok kontrol negatif. Hal ini terjadi karena asam mefenamat menghambat sintesis prostaglandin sehingga aliran darah pada mukosa lambung berkurang dan menyebabkan hilangnya lapisan mukus yang melindungi mukosa lambung. ${ }^{5,6,7}$ Gambaran mikroskopik menunjukkan peradangan akut pada daerah bagian bawah mukosa lambung, terlihat adanya infiltrasi sel-sel radang limfosit plasma dan PMN yang banyak. Hal ini sesuai dengan teori yang mengatakan bahwa asam mefenamat dapat merusak mukosa lambung secara langsung serta dapat mengurangi sekresi ion bikarbonat dan sekresi mukus. Akibatnya sistem pertahanan dari lambung terganggu dan terjadilah proses peradangan akut (gastritis akut) yang ditandai dengan adanya sel-sel radang limfosit plasma dan PMN pada daerah mukosa. ${ }^{4-7}$

Gambaran makroskopik kelompok tikus wistar dengan perlakuan pemberian asam mefenamat $10 \mathrm{mg}$ per hari selama 7 hari dilanjutkan dengan perasan lengkuas $16 \mathrm{mg}$ per hari selama 7 hari menunjukkan lambung berwarna merah pucat. Secara mikroskopik terlihat adanya peradangan yang tidak hebat dibanding dengan kelompok perlakuan yang diberikan asam mefenamat saja. Ini menunjukkan bahwa perasan lengkuas memiliki efek penyembuhan pada lambung. Pada lengkuas terdapat senyawa 1'asetoxy chavikol acetate, flavonoid dan saponin. 1'asetoxy chavikol acetate dapat memperlambat atau menghambat oksidasi dengan cara menangkap radikal bebas dan menghambat enzim oksidatif yang dihasilkan selama cedera sel yang diakibatkan oleh asam mefenamat. Selain itu1'asetoxy chavikol acetate juga dapat menurunkan sitokin-sitokin yang diproduksi sel helper T. Flavonoid dapat meningkatkan prostaglandin pada mukosa lambung, dan juga dapat mencegah pembentukan radikal bebas yang membuat lambung menjadi ulseratif dan erosif. Saponin dapat mengaktivasi membran pelindung mukosa lambung. Dengan demikian lengkuas dapat mengurangi peradangan sehingga respon cedera pada sel pun berkurang. Dengan berkurangnya cedera sel, maka infiltrasi sel-sel radang limfosit dan PMN pada mukosa lambung berkurang. ${ }^{8,9,12}$

Pada kelompok tikus wistar dengan perlakuan pemberian asam mefenamat 10 mg per hari selama 7 hari dilanjutkan dengan pemberian pelet standar secara makroskopik tampak berwarna merah pucat. Gambaran mikroskopik menunjukkan masih banyak infiltrasi sel-sel radang limfosit plasma dan PMN di daerah bagian submukosa lambung dibandingkan dengan tikus kelompok $\mathrm{C}$ yang diberikan lengkuas dan jumlahnya lebih sedikit dibandingkan dengan tikus kelompok $\mathrm{B}$ yang hanya diberikan asam mefenamat.Berkurangnya sel-sel radang pada kelompok ini terjadi lebih lambat dibanding dengan kelompok $\mathrm{C}$ yang proses penyembuhannya dibantu dengan pemberian lengkuas. Pada lambung yang mengalami cedera sel-sel epitel mukosa dapat beregenerasi pada 2-6 hari dan berlanjut selama beberapa minggu, bergantung pada besarnya kerusakan yang terjadi. $^{5,6,13}$ 


\section{SIMPULAN}

Dari penelitian ini dapat disimpulkan bahwa perasan lengkuas dapat menurunkan sel-sel radang yang diinduksi dengan asam mefenamat.

\section{UCAPAN TERIMA KASIH}

Ucapan terima kasih disampaikan pada dr. Jane Wuisan, MS, SpFK dan dr. Carla Kairupan, $\mathrm{PhD}$, dan pada semua pihak yang baik secara langsung maupun tidak langsung telah menumbuhkan ide/gagasan dalam pemikiran penulisan sehingga dapat menyelesaikan artikel ini.

\section{DAFTAR PUSTAKA}

1. Utami P. Buku Pintar Tanaman Obat. Jakarta: PT Agromedia Pustaka; 2008.

2. Snell RS. Abdomen: Bagian II Cavitas Abdomilanis. Dalam: Anatomi Klinik untuk Mahasiswa Kedokteran (Edisi Keenam). Jakarta: EGC, 2006; p.216-8.

3. Loho L. Patologi Saluran Pencernaan. Manado: Bagian Patologi Anatomi Fakultas Kedokteran Universitas Samratulangi; 2002.

4. Setiawan S. Makalah Farmakologi Asam Mefenamat. Banjarmasin: Bagian Keperawatan Sekolah Tinggi Ilmu Kesehatan Muhamadiyah; 2010.

5. Robbins, Kumar, Abbas, Cotran. The Gastrointestinal Tract. In: Schmitt W, Gruliow R, editors. Pathologic Basis of Disease (Eigth Edition). American: Saunder Elsevier, 2010; p.495-7.
6. Robbins, Kumar, Abbas, Cotran. The oral cavity and The Gastrointestinal Tract. In: Schmitt W, Gruliow R, editors. Basic of Pathology (Eigth Edition). American: Saunder Elsevier, 2010; p.591-3.

7. Kumar, Cotran, Robbins. Sistem Pencernaan. Dalam: Hartanto H, Darmaniah N, Asroruddin M, editor. Buku Ajar Patologi (Edisi Ketujuh). Jakarta: Penerbit Kedokteran EGC, 2007; p.624-6.

8. Nuansrithong $P$, Chumbuajan $O$, Sirintharawech N, Chantip D. Gastroprotective Effect of The Extract From Alpinia Galanga in Rats and The Possible Mechanism. Journal of Science and Technology. 2008; 8(2):38-45.

9. Ghosh AK, Banerjee M, Bhattacharya NK. Anti-inflamatory activity of root of Alpinia Galanga Willd. Journal of Pharmacology. 2011;2(3):139-43.

10. Sulistia G, Wilamana PF. AnalgesikAntipiretik Analgesik Anti-Inflamasi Nonsteroid dan Obat Gangguan Sendi Lainnya. Dalam: Gunawan SG, Setiabudy R, Nafriadi, Elysabeth, editor. Farmakologi dan Terapi (Edisi Kelima). Jakarta: Balai Penerbit FKUI, 2008; p.230-46.

11. Scope M. Galangal: Botanical Description \& Habitat [homepage on the Internet]. Nodate [cited 2012 Oct 22]. Available from: http://www.appliedhealth.com/.

12. Borrelli F, Izzo A. The Plant Kingdom as a Source of Anti-ulcer Remedies. Phytoteraphy Research. 2007:14;581-91.

13. Kumar, Cotran, Robbins. Pemulihan Jaringan. Dalam: Hartanto H, Darmaniah $\mathrm{N}$, Asroruddin $\mathrm{M}$, editor. Buku Ajar Patologi (Edisi Ketujuh). Jakarta: Penerbit Kedokteran EGC, 2007; p.78-81. 